\title{
Electrochemical Corrosion Testing of Borated Stainless Steel Alloys
}

Tedd Lister

Ron Mizia

Arnold Erickson

Sandra Birk

May 2007

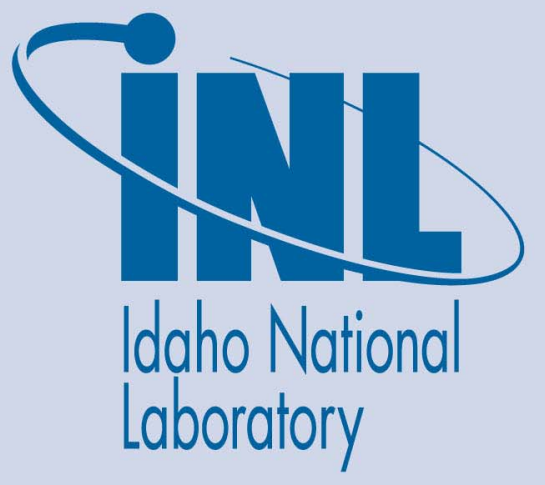

The INL is a U.S. Department of Energy National Laboratory operated by Battelle Energy Alliance 
INL/EXT-07-12633

\title{
Electrochemical Corrosion Testing of Borated Stainless Steel Alloys
}

\author{
Tedd Lister \\ Ron Mizia \\ Arnold Erickson \\ Sandra Birk
}

May 2007

Idaho National Laboratory

Idaho Falls, Idaho 83415

Prepared for the

U.S. Department of Energy

Office of Civilian Radioactive Waste Management

Under DOE Idaho Operations Office

Contract DE-AC07-05ID14517 


\section{Electrochemical Corrosion Testing of Borated Stainless Steel Alloys}

INL/EXT-07-12633

May 2007
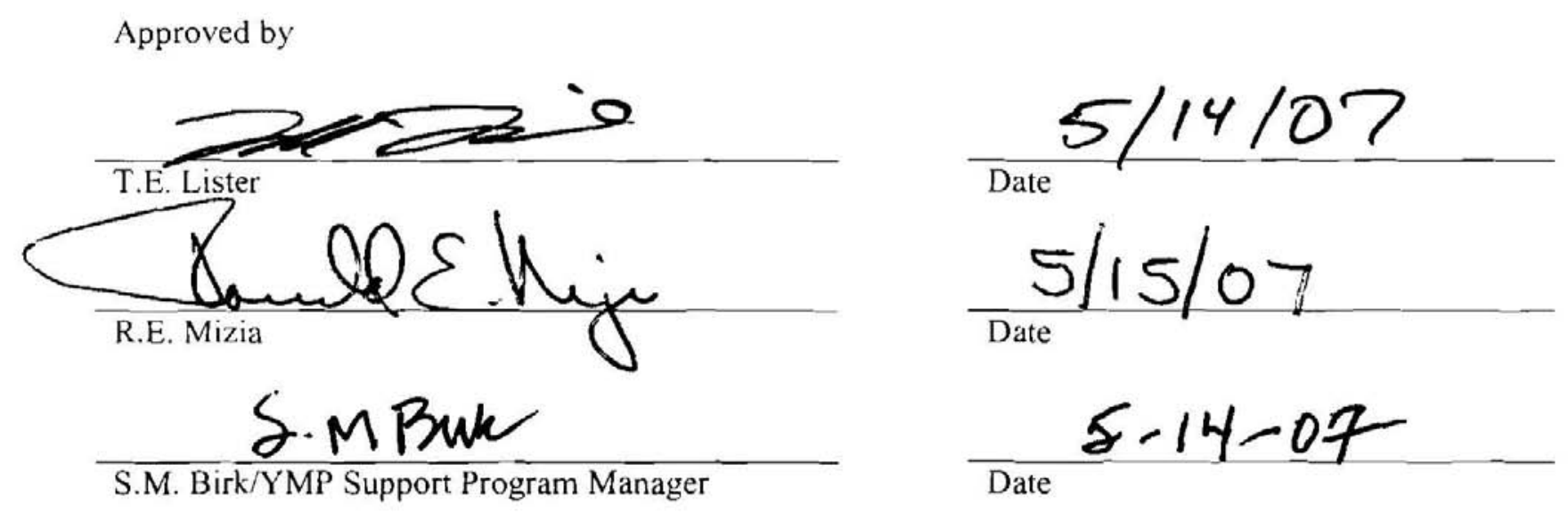



\begin{abstract}
The Department of Energy Office of Civilian Radioactive Waste Management has recommended borated stainless steel manufactured to the requirements of ASTM A 887-89, Grade A, UNS S30464, to be the material used for the fabrication of the fuel basket internals of the preliminary transportation, aging, and disposal canister system preliminary design. The long-term corrosion resistance performance of this class of borated materials must be verified when exposed to expected YMP repository conditions after a waste package breach.

Electrochemical corrosion tests were performed on crevice corrosion coupons of Type 304B4 and Type 304B5 borated stainless steels exposed to single postulated in-package chemistry at $60^{\circ} \mathrm{C}$. The results show low corrosion rates for the test period.
\end{abstract}




\section{CONTENTS}

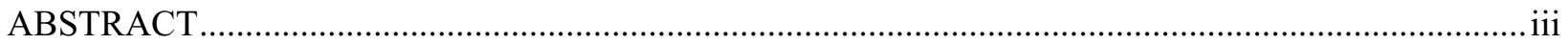

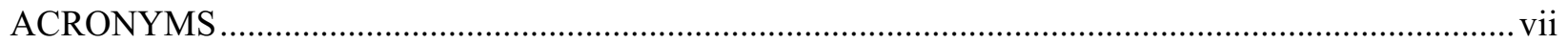

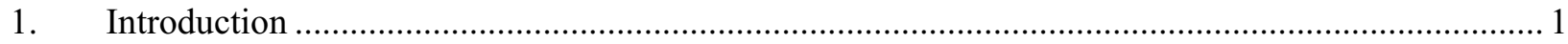

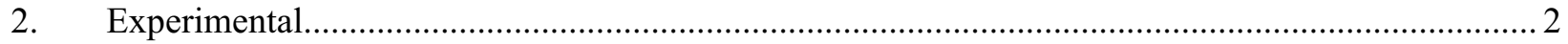

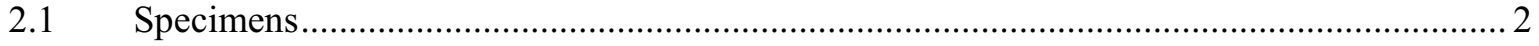

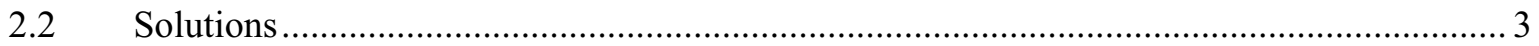

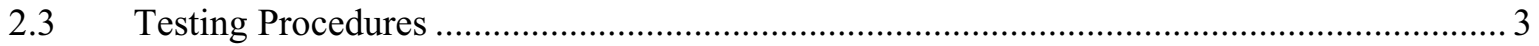

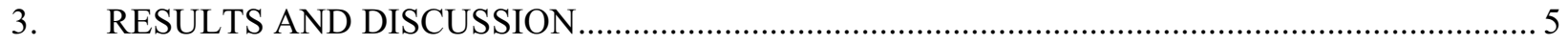

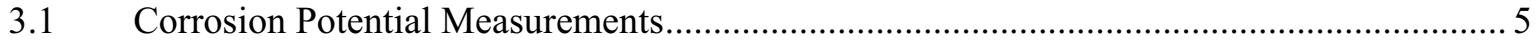

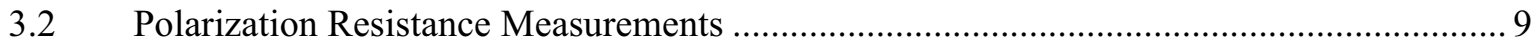

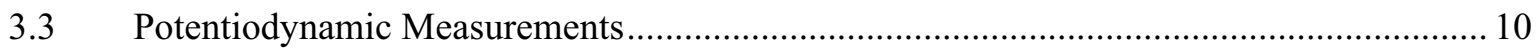

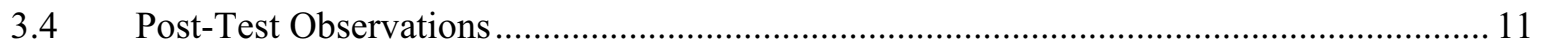

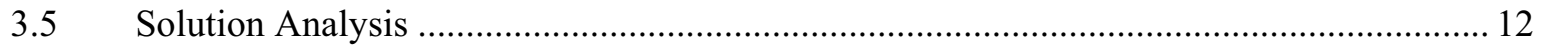

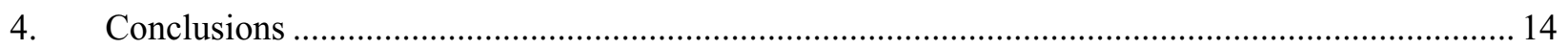

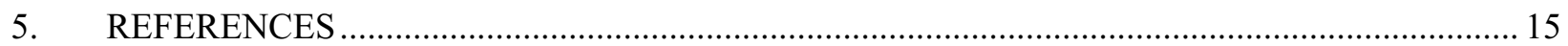

\section{FIGURES}

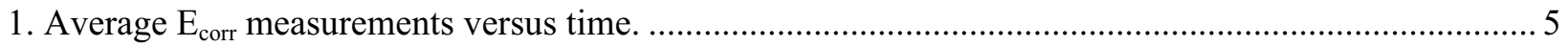

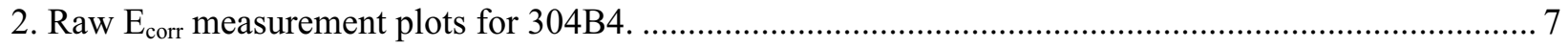

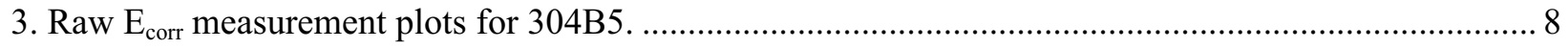

4. Corrosion rates versus time plots obtained by LPR measurements. .................................................. 10

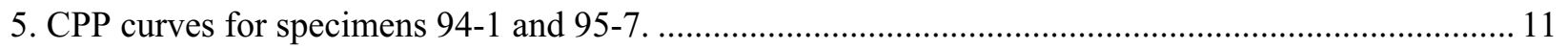

6. Specimen appearance of 304B4 specimens (94-1, 94-2, and 94-5, left to right).............................. 11

7. Specimen appearance of 304B5 specimens (95-7, 95-8, and 95-9, left to right)................................ 11

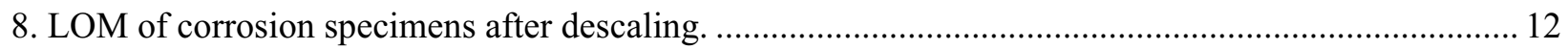




\section{TABLES}

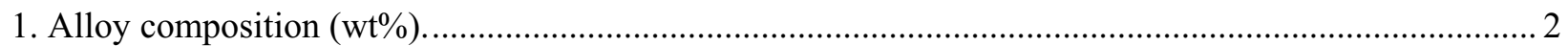

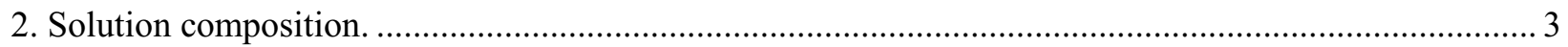

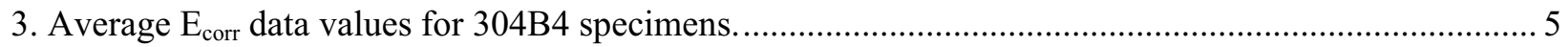

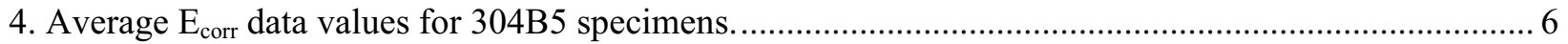

5. Corrosion rates for 304B4 specimens obtained from LPR measurement. .......................................... 9

6. Corrosion rates for 304B5 specimens obtained from LPR measurement. ........................................ 9

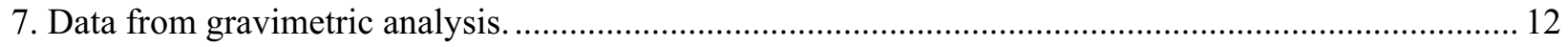

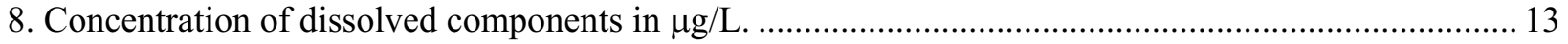




\section{ACRONYMS}

ACS American Chemical Society

ASTM American Society for Testing and Materials

CARTECH Carpenter Technology Corporation

CPP Cyclic Potentiodynamic Polarization

CR corrosion rate

DOE-RW U.S. Department of Energy, Office of Civilian Radioactive Waste Management

HIP hot isostatic pressing

INL Idaho National Laboratory

LLNL Lawrence Livermore National Laboratory

LOM light optical microscopy

LPR linear polarization resistance

SCE saturated calomel reference electrode

YMP Yucca Mountain Project 


\section{Electrochemical Corrosion Testing of Borated Stainless Steel Alloys}

\section{INTRODUCTION}

The Yucca Mountain Project (YMP) has been directed by the U.S. Department of Energy, Office of Civilian Radioactive Waste Management (DOE-RW) to develop a new repository waste package design based on the transport, aging, and disposal canister system concept. A neutron poison material for fabrication of the internal spent nuclear fuel baskets for these canisters needs to be identified. A material that has been used for criticality control in wet and dry storage of spent nuclear fuel is borated stainless steel. ${ }^{1}$ These stainless steel products are available as an ingot metallurgy plate product with a molybdenum addition $^{\mathrm{a}}$ and a powder metallurgy product ${ }^{\mathrm{b}}$ that meets the requirements of American Society for Testing and Materials (ASTM) A887, Grade A. Previous non-quality affecting test data has shown that the Grade A material had better localized corrosion performance under conditions similar to those tested earlier at the INL. In addition, the localized corrosion resistance was found to be reduced as the amount of boron is increased in the Grade A alloys.

This report will summarize the results of quality affecting tests of two borated stainless steel alloys in solutions representative of ionic compositions inside the waste package should a breach occur. The two alloys in these tests are Neutrosorb Plus 304B4 Grade A and 304B5 Grade A (Reference 1) (powder metallurgy, hot rolled).

a. Bohler Bleche GmbH, P.O. Box 28, Murzzuschlag, Austria

b. Carpenter Technology Corp.(CARTECH) P.O. Box 14662, Reading, PA 


\section{EXPERIMENTAL}

The testing was performed in accordance with Idaho National Laboratory (INL) procedures and specific requirements contained in INL document PLN-2320. ${ }^{2}$ The experimental plan outlining this work was PLN-2313. ${ }^{3}$ PLN-2314 ${ }^{4}$ was developed from the YMP Technical Work Plan. ${ }^{5}$

\subsection{Specimens}

The specimens were machined from plate stock. Table 1 shows the chemical composition of the two alloys as measured by Laboratory Testing Inc.

Table 1. Alloy composition and ASTM specifications (wt\%).

\begin{tabular}{|c|c|c|c|c|}
\hline Alloy & 304B4 Grade A & \begin{tabular}{|c|} 
304B4 specification \\
${ }^{*}$ \\
ASTM A 887-89
\end{tabular} & 304B5 Grade A & $\begin{array}{c}\text { 304B5 specification }^{*} \\
\text { ASTM A 887-89 }\end{array}$ \\
\hline Heat \# & 182194 & & 182195 & \\
\hline Name & 304B4 & & 304B5 & \\
\hline $\mathrm{Cr}$ & 19.46 & $18.00-20.00$ & 19.36 & $18.00-20.00$ \\
\hline $\mathrm{Ni}$ & 13.32 & $12.00-15.00$ & 13.39 & $12.00-15.00$ \\
\hline $\mathrm{B}$ & 1.17 & $1.00-1.24$ & 1.32 & $1.25-1.49$ \\
\hline $\mathrm{C}$ & 0.05 & 0.08 & 0.05 & 0.08 \\
\hline $\mathrm{N}$ & 0.01 & 0.1 & 0.01 & 0.1 \\
\hline $\mathrm{P}$ & 0.002 & 0.045 & 0.001 & 0.045 \\
\hline S & 0.003 & 0.030 & 0.002 & 0.030 \\
\hline Co & 0.03 & 0.2 & 0.03 & 0.2 \\
\hline $\mathrm{Si}$ & 0.69 & 0.75 & 0.66 & 0.75 \\
\hline $\mathrm{Mn}$ & 1.91 & 2.00 & 1.84 & 2.00 \\
\hline $\mathrm{Fe}$ & Bal & NA & $\mathrm{Bal}$ & NA \\
\hline
\end{tabular}

* Maximum value unless range is given.

The Grade A material from heats 182194 and 182195 was fabricated by CARTECH using the powder metallurgy process (Footnote a). This involves full density consolidation of inert-gas atomized powders by hot isostatic pressing (HIP). The HIP compacts were forged and hot rolled into plate. The asreceived plate has HIP can material (Type 304 stainless steel) on the top and bottom surfaces, which were removed by machining during the coupon fabrication process to test the borated stainless-steel matrix only.

The crevice corrosion specimen design is based on a Lawrence Livermore National Laboratory (LLNL) specimen design and is a controlled INL document. ${ }^{6}$ The specimens were $0.75 \times 0.75 \times 0.375$ in. with a 0.28 in. through-hole for the crevice assembly. Specimens 94-1, 94-2, and 94-3 were machined from Heat 182194 (304B4). Specimens 95-7, 94-8, and 94-9 were machined from Heat 182195 (304B5). The specimens were wet sanded with 240-, 400-, and 600-grit $\mathrm{SiC}$ sandpaper prior to testing. Specimens had their electrical connection sealed via a Teflon compression fitting. Surface areas were calculated using the six external surfaces of the block and the inner surface of the crevice bolt hole. 
The crevice formers used in the test were multiple crevice assembly type, made of ceramic. The mating surfaces were wet sanded with 600 -grit sandpaper to smooth the as-received surfaces. The crevice formers were attached to the specimens with fasteners made of alloy C-276. Teflon tape was wrapped on the crevice bolt to electrically isolate from the specimen. A torque of $50 \mathrm{in}-\mathrm{oz}$ was applied to the crevice bolt for all tests.

\subsection{Solutions}

The composition of the solution used in these tests is shown in Table 2. These compositions were supplied by the YMP Technical Work Plan covering this work (Reference 4). This solution is based on expected compositions (major ions) for in-package chemistry. The solution for each vessel was mixed separately. Chemicals were American Chemical Society (ACS) grade and obtained from the YMP approved supplier (Ultra Scientific). The equilibrium $\mathrm{pH}$ of the solution with aeration was approximately 5.9. The $\mathrm{pH}$ was adjusted to 5.5 during aeration using drops of a dilute $\mathrm{HCl}$ solution. A separate solution was prepared for each test vessel prior to the test initiation. A solution volume of 2.5 liters was added to each vessel.

Table 2. Solution composition.

\begin{tabular}{|c|c|c|c|c|c|c|}
\hline Test Solution & {$\left[\mathrm{Cl}^{-}\right](\mathrm{m})$} & {$[\mathrm{F}](\mathrm{m})$} & {$\left[\mathrm{NO}_{3}^{-}\right](\mathrm{m})$} & $\mathrm{pH}$ & $\mathrm{NO}_{3} / \mathrm{Cl}$ & $\mathrm{NO}_{3} /(\mathrm{Cl}+\mathrm{F})$ \\
\hline B3 & 0.004 & 0.001 & 0.0025 & 5.5 & 0.63 & 0.50 \\
\hline
\end{tabular}

\subsection{Testing Procedures}

The testing procedures are contained within INL document PLN-2314 (Reference 6). Each vessel (cell) held three specimens, with one containing the 304B4 specimens (Vessel 1) and the other containing 304B5 specimens (Vessel 2). All tests were performed at $60^{\circ} \mathrm{C}$ maintained by thermocouple-based temperature controllers. The heating was supplied by a mantle under the cell. The temperature of the cell was confirmed using a calibrated thermometer before the initiation and during the test. The cell was fitted with a condenser to prevent solution loss during the test. This condenser was chilled with $5^{\circ} \mathrm{C}$ water. The saturated calomel reference electrode (SCE) was connected through a Luggin capillary. A single platinum foil flag $(1 \times 1$ in.) was employed as the counter electrode. The exposure time was approximately 4 weeks.

Corrosion potential $\left(\mathrm{E}_{\mathrm{corr}}\right)$ measurements were performed at intervals during the test. Each involved measuring $\mathrm{E}_{\text {corr }}$ for a 10-minute period. An average $\mathrm{E}_{\text {corr }}$ value was calculated from each 10-minute period and used in the $\mathrm{E}_{\text {corr }}$ versus time plots in Excel.

Linear polarization resistance (LPR) data were taken approximately once per week for each specimen. The scan rate was $0.025 \mathrm{mV} / \mathrm{sec}$ from starting at ${ }^{-} 20 \mathrm{mV}$ versus $E_{\text {corr }}$ and scanning to ${ }^{+} 20 \mathrm{mV}$ versus $E_{\text {corr }}$. The $E_{\text {corr }}$ value was measured by the potentiostat just prior to test initiation as a part of the LPR routine. This data was analyzed by the software package (Gamry Echem Analyst version 1.35) that was installed by the potentiostat manufacturer and validated using INL procedures. The software supplied a polarization resistance value (in ohms) that was used to calculate the corrosion rate (CR) from equations from ASTM G102 Section 5. The equivalent weight was calculated from ASTM G102 Section 4.2 using the following final oxidation states $\left(\mathrm{Cr}^{+3}, \mathrm{Fe}^{+2}, \mathrm{Ni}^{+2}, \mathrm{~B}^{+3}, \mathrm{Mn}^{+2}\right)$. The calculated equivalent weight values (dimensionless units) were 23.44 for 304B 4 and 23.26 for 304B5. A density value of $7.77 \mathrm{~g} / \mathrm{cm}^{3}$ was used. $^{7}$ 
At the end of testing, a potentiodynamic test was performed on one specimen from each corrosion vessel. This test method is also referred to as cyclic potentiodynamic polarization (CPP). The solution was purged with $\mathrm{N}_{2}$ gas at least one hour prior to measurement. The scan was performed at $0.166 \mathrm{mV} / \mathrm{sec}$ from $-0.2 \mathrm{~V}$ of the measured $\mathrm{E}_{\text {corr }}$ to $0.8 \mathrm{~V}$ versus $\mathrm{SCE}$ and returned to the starting potential. The curves were analyzed to determine the breakdown $\left(\mathrm{E}_{\mathrm{bd}}\right)$ and repassivation $\left(\mathrm{E}_{\mathrm{rp}}\right)$ potentials. 


\section{RESULTS AND DISCUSSION}

\subsection{Corrosion Potential Measurements}

The corrosion potentials $\left(\mathrm{E}_{\text {corr }}\right)$ for each specimen were measured twice per week during the testing. A plot of the averaged data value versus time is shown in Figure 1. A table of this data is shown in Tables 3 and 4 . The data shows a general trend of increasing $E_{\text {corr }}$ initially during the test then leveling off. The values for the three specimens in each vessel are in good agreement for all measurements. The 304B4 specimens attained a slightly more ennobled $\mathrm{E}_{\text {corr }}$ value. Figures 2 and 3 show all the $\mathrm{E}_{\text {corr }}$ data during the tests. No signs of extreme variation due to pitting corrosion were observed during the measurements. Because pitting corrosion signatures (negative potential spikes) had been observed in previous testing under similar conditions, ${ }^{8}$ it is thought that the short measurement period limited the window enough to exclude those events.
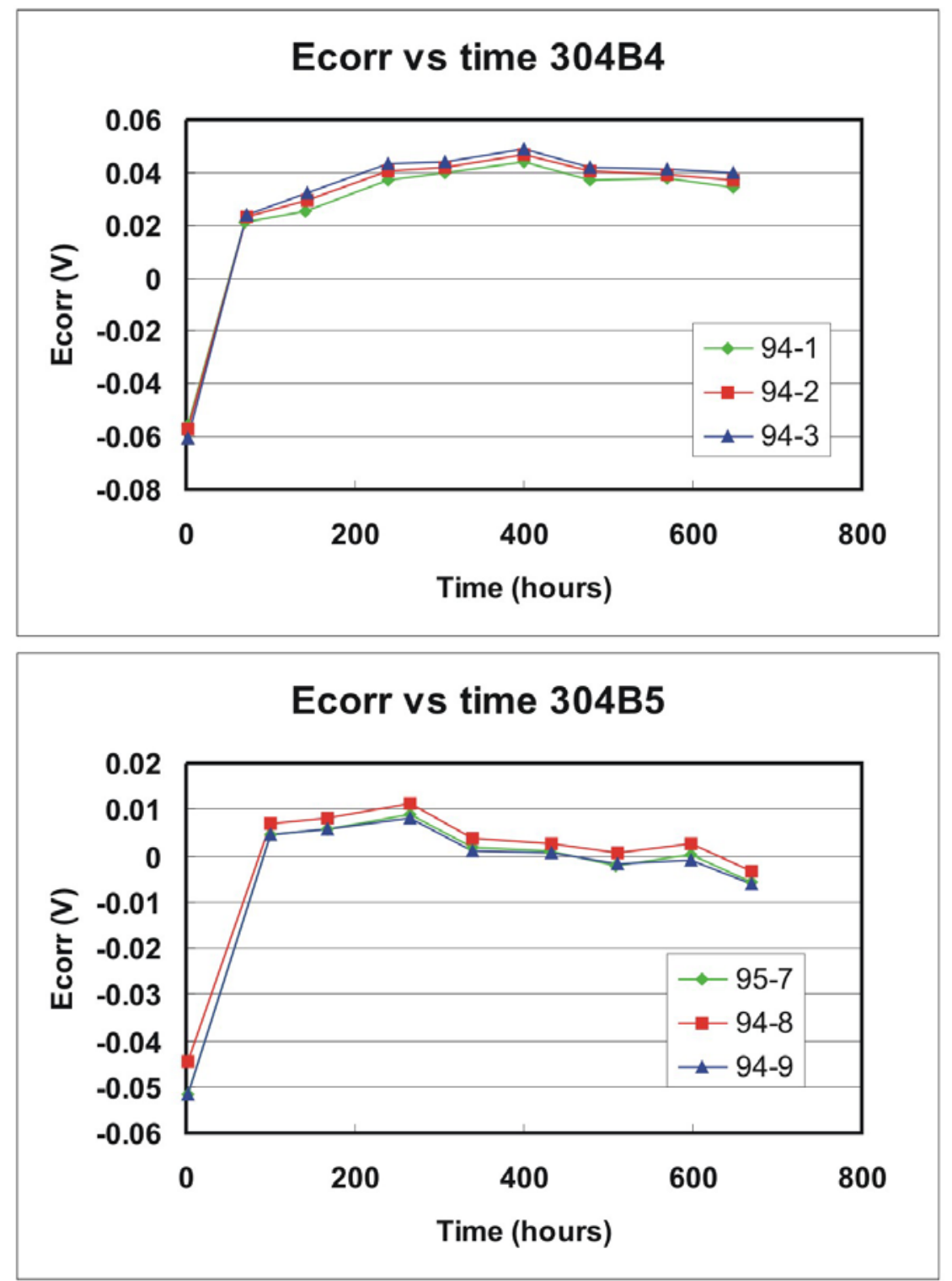

Figure 1. Average $\mathrm{E}_{\text {corr }}$ measurements versus time. 
Table 3. Average $\mathrm{E}_{\text {corr }}$ data values for 304B4 specimens.

\begin{tabular}{|c|c|c|c|c|c|c|}
\hline \multicolumn{3}{|c|}{$94-1$} & \multicolumn{2}{|l|}{$94-2$} & \multicolumn{2}{|l|}{$94-3$} \\
\hline Point & Hours & $\begin{array}{l}E_{\text {corr }} \\
\text { (V) }\end{array}$ & Hours & $\begin{array}{l}E_{\text {corr }} \\
\text { (V) }\end{array}$ & Hours & $\begin{array}{l}E_{\text {corr }} \\
\text { (V) }\end{array}$ \\
\hline 1 & 2.43 & $-5.56 \mathrm{E}-02$ & 2.25 & $-5.72 \mathrm{E}-02$ & 2.62 & $-6.05 \mathrm{E}-02$ \\
\hline 2 & 69.28 & $2.12 \mathrm{E}-02$ & 70.78 & $2.36 \mathrm{E}-02$ & 70.68 & $2.40 \mathrm{E}-02$ \\
\hline 3 & 142.2 & $2.54 \mathrm{E}-02$ & 142.42 & $2.95 \mathrm{E}-02$ & 142.62 & $3.24 \mathrm{E}-02$ \\
\hline 4 & 238.23 & $3.73 \mathrm{E}-02$ & 238.47 & $4.03 \mathrm{E}-02$ & 238.67 & 4.34E-02 \\
\hline 5 & 305.82 & $3.99 \mathrm{E}-02$ & 306.07 & $4.17 \mathrm{E}-02$ & 306.25 & 4.43E-02 \\
\hline 6 & 400.47 & 4.41E-02 & 400.85 & 4.69E-02 & 400.67 & 4.87E-02 \\
\hline 7 & 477.2 & $3.69 \mathrm{E}-02$ & 477.43 & $4.08 \mathrm{E}-02$ & 477.67 & $4.20 \mathrm{E}-02$ \\
\hline 8 & 570.17 & $3.78 \mathrm{E}-02$ & 570.35 & $3.90 \mathrm{E}-02$ & 570.53 & $4.14 \mathrm{E}-02$ \\
\hline 9 & 648.38 & $3.41 \mathrm{E}-02$ & 648.63 & $3.72 \mathrm{E}-02$ & 648.85 & $3.99 \mathrm{E}-02$ \\
\hline
\end{tabular}

Table 4. Average $\mathrm{E}_{\text {corr }}$ data values for 304B5 specimens.

\begin{tabular}{|c|c|c|c|c|c|c|}
\hline \multicolumn{3}{|c|}{$95-7$} & \multicolumn{2}{|l|}{$95-8$} & \multicolumn{2}{|l|}{$95-9$} \\
\hline Point & Hours & $\begin{array}{c}E_{\text {corr }} \\
\text { (V) }\end{array}$ & Hours & $\begin{array}{c}E_{\text {corr }} \\
\text { (V) }\end{array}$ & Hours & $\begin{array}{c}E_{\text {corr }} \\
(\mathrm{V})\end{array}$ \\
\hline 1 & 1.78 & $-5.15 \mathrm{E}-02$ & 2.15 & $-4.44 \mathrm{E}-02$ & 2.43 & $-5.15 \mathrm{E}-02$ \\
\hline 2 & 99.48 & 4.53E-03 & 99.68 & $6.86 \mathrm{E}-03$ & 99.87 & $4.53 \mathrm{E}-03$ \\
\hline 3 & 167.18 & $5.73 \mathrm{E}-03$ & 167.39 & $8.00 \mathrm{E}-03$ & 167.58 & $5.73 \mathrm{E}-03$ \\
\hline 4 & 264.15 & $8.72 \mathrm{E}-03$ & 264.33 & $1.13 \mathrm{E}-02$ & 264.52 & $8.18 \mathrm{E}-03$ \\
\hline 5 & 338.52 & $1.75 \mathrm{E}-03$ & 338.82 & $3.80 \mathrm{E}-03$ & 339 & $1.01 \mathrm{E}-03$ \\
\hline 6 & 431.32 & $8.75 \mathrm{E}-04$ & 431.58 & $2.63 \mathrm{E}-03$ & 431.78 & $7.00 \mathrm{E}-04$ \\
\hline 7 & 509.65 & $-2.20 \mathrm{E}-03$ & 509.87 & $6.76 \mathrm{E}-04$ & 510.08 & $-1.94 \mathrm{E}-03$ \\
\hline 8 & 598.43 & $4.01 \mathrm{E}-05$ & 598.68 & $2.44 \mathrm{E}-03$ & 598.87 & $-8.82 \mathrm{E}-04$ \\
\hline 9 & 669.05 & $-5.87 \mathrm{E}-03$ & 669.23 & $-3.33 \mathrm{E}-03$ & 669.42 & $-6.14 \mathrm{E}-03$ \\
\hline
\end{tabular}



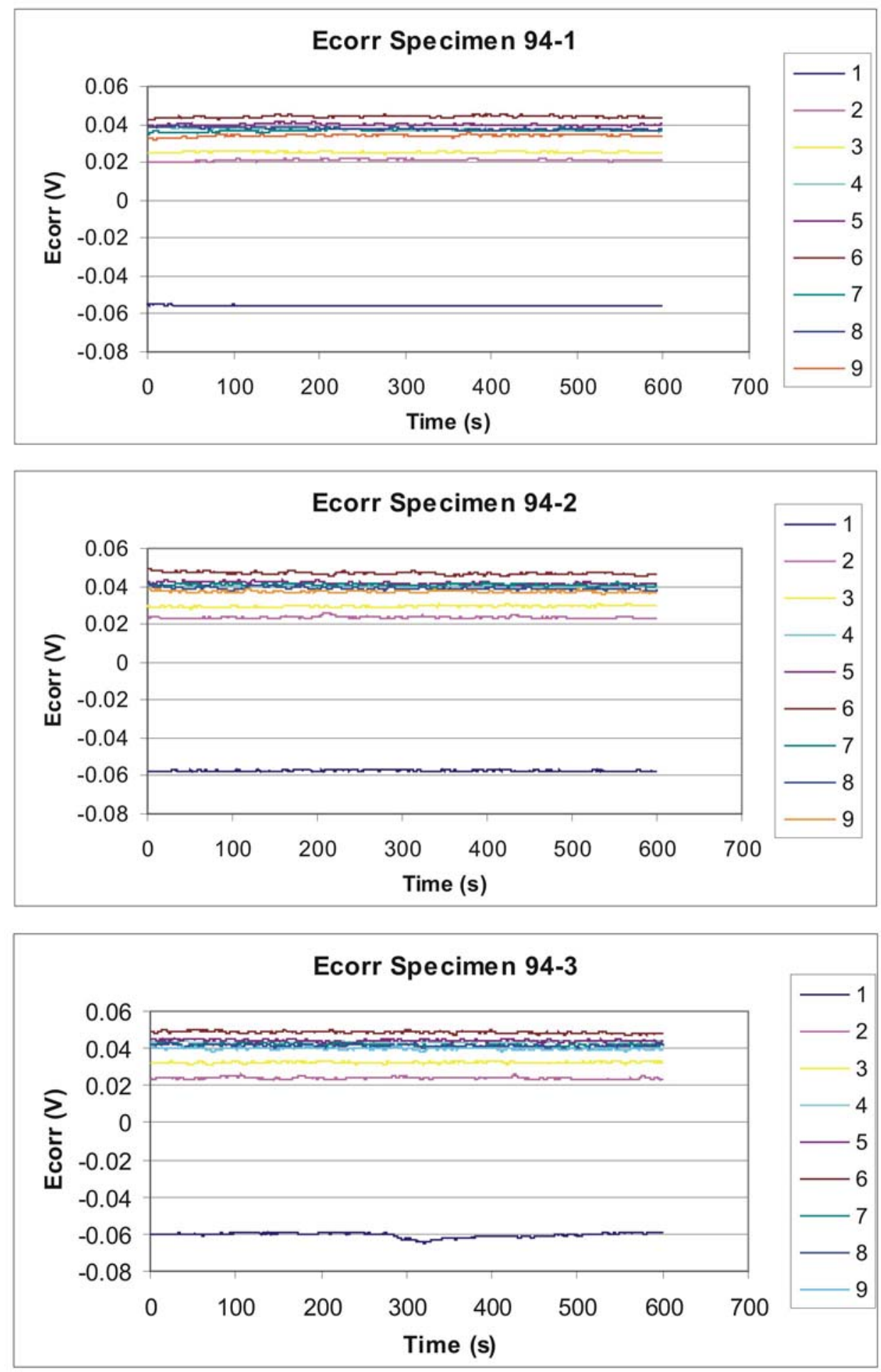

Figure 2. Raw $\mathrm{E}_{\text {corr }}$ measurement plots for 304B4. 

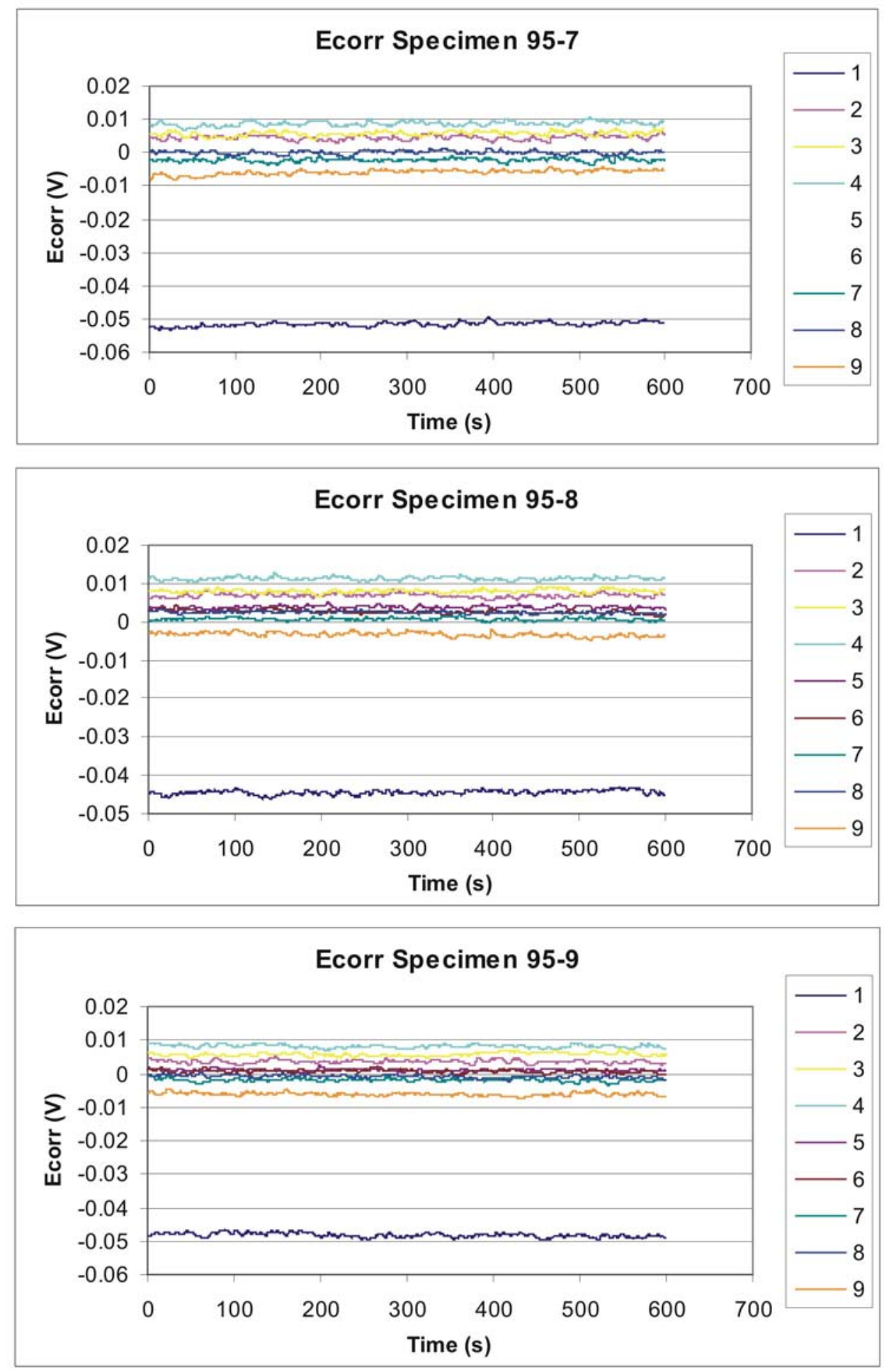

Figure 3. Raw $\mathrm{E}_{\text {corr }}$ measurement plots for 304B5. 


\subsection{Polarization Resistance Measurements}

LPR measurements were performed once per week during the tests. The currents were very low, generally less than $100 \mathrm{nA}$. Significant noise was observed due to the low currents, low ionic concentrations, and lack of Faraday shielding. Despite this, relatively consistent corrosion rates were calculated from the data. Tables 5 and 6 show the corrosion rates obtained from the testing. These data points are plotted versus time in Figure 4 . The rates were all below $0.05 \mu \mathrm{m} / \mathrm{yr}$ except for one value indicating a low passive current. A single value that was significantly higher for 304B5. This was ascribed to a localized corrosion spike changing the $\mathrm{E}_{\text {corr }}$ negative during the initial $\mathrm{E}_{\text {corr }}$ measurement performed by the software before the scan.

Table 5. Corrosion rates for 304B4 specimens obtained from LPR measurement.

\begin{tabular}{|c|c|c|c|c|}
\hline Specimen & $\begin{array}{c}\text { Exposure time } \\
\text { (hours) }\end{array}$ & $\begin{array}{c}\mathrm{CR} \\
(\mu \mathrm{m} / \mathrm{yr})\end{array}$ & $\begin{array}{c}\text { Average CR } \\
(\mu \mathrm{m} / \mathrm{yr})\end{array}$ & $\begin{array}{c}\text { StDev } \\
(\mu \mathrm{m} / \mathrm{yr})\end{array}$ \\
\hline $94-1$ & 72.47 & $3.61 \mathrm{E}-02$ & & \\
$94-2$ & 72.93 & $4.44 \mathrm{E}-02$ & & $6.78 \mathrm{E}-03$ \\
$94-3$ & 73.38 & $3.09 \mathrm{E}-02$ & $3.71 \mathrm{E}-02$ & \\
$94-1$ & 239.55 & $1.39 \mathrm{E}-02$ & & $3.20 \mathrm{E}-03$ \\
$94-2$ & 240.33 & $1.93 \mathrm{E}-02$ & & \\
$94-3$ & 240.8 & $1.96 \mathrm{E}-02$ & $1.76 \mathrm{E}-02$ & \\
$94-1$ & 405.87 & $3.61 \mathrm{E}-02$ & & $1.01 \mathrm{E}-02$ \\
$94-2$ & 406.45 & $2.90 \mathrm{E}-02$ & & \\
$94-3$ & 406.9 & $1.63 \mathrm{E}-02$ & $2.71 \mathrm{E}-02$ & \\
$94-1$ & 574.55 & $2.53 \mathrm{E}-02$ & & $3.58 \mathrm{E}-03$ \\
$94-2$ & 575.05 & $2.34 \mathrm{E}-02$ & & \\
$94-3$ & 575.52 & $3.03 \mathrm{E}-02$ & $2.63 \mathrm{E}-02$ & \\
\hline
\end{tabular}

Table 6. Corrosion rates for 304B5 specimens obtained from LPR measurement.

$\begin{array}{ccccc}\text { Specimen } & \begin{array}{c}\text { Exposure time } \\ \text { (hours) }\end{array} & \begin{array}{c}\text { CR } \\ (\mu \mathrm{m} / \mathrm{yr})\end{array} & \begin{array}{c}\text { Average CR } \\ (\mu \mathrm{m} / \mathrm{yr})\end{array} & \begin{array}{c}\text { StDev } \\ (\mu \mathrm{m} / \mathrm{yr})\end{array} \\ 95-7 & 102 & 3.80 \mathrm{E}-02 & & \\ 95-8 & 102.58 & 3.74 \mathrm{E}-02 & & 1.54 \mathrm{E}-03 \\ 95-9 & 103.18 & 3.51 \mathrm{E}-02 & 3.68 \mathrm{E}-02 & \\ 95-7 & 272.02 & 7.29 \mathrm{E}-03 & & 1.10 \mathrm{E}-02 \\ 95-8 & 268.55 & 2.87 \mathrm{E}-02 & & \\ 95-9 & 269 & 2.25 \mathrm{E}-02 & 1.95 \mathrm{E}-02 & \\ 95-7 & 436.72 & 2.53 \mathrm{E}-01 & & \\ 95-8 & 437.28 & 1.51 \mathrm{E}-02 & & \\ 95-9 & 437.77 & 1.28 \mathrm{E}-02 & 9.38 \mathrm{E}-02 & \\ 95-7 & 599.08 & 2.63 \mathrm{E}-02 & & 7.50 \mathrm{E}-03 \\ 95-8 & 599.6 & 1.58 \mathrm{E}-02 & & \\ 95-9 & 600.06 & 1.18 \mathrm{E}-02 & 1.80 \mathrm{E}-02 & \\ \end{array}$



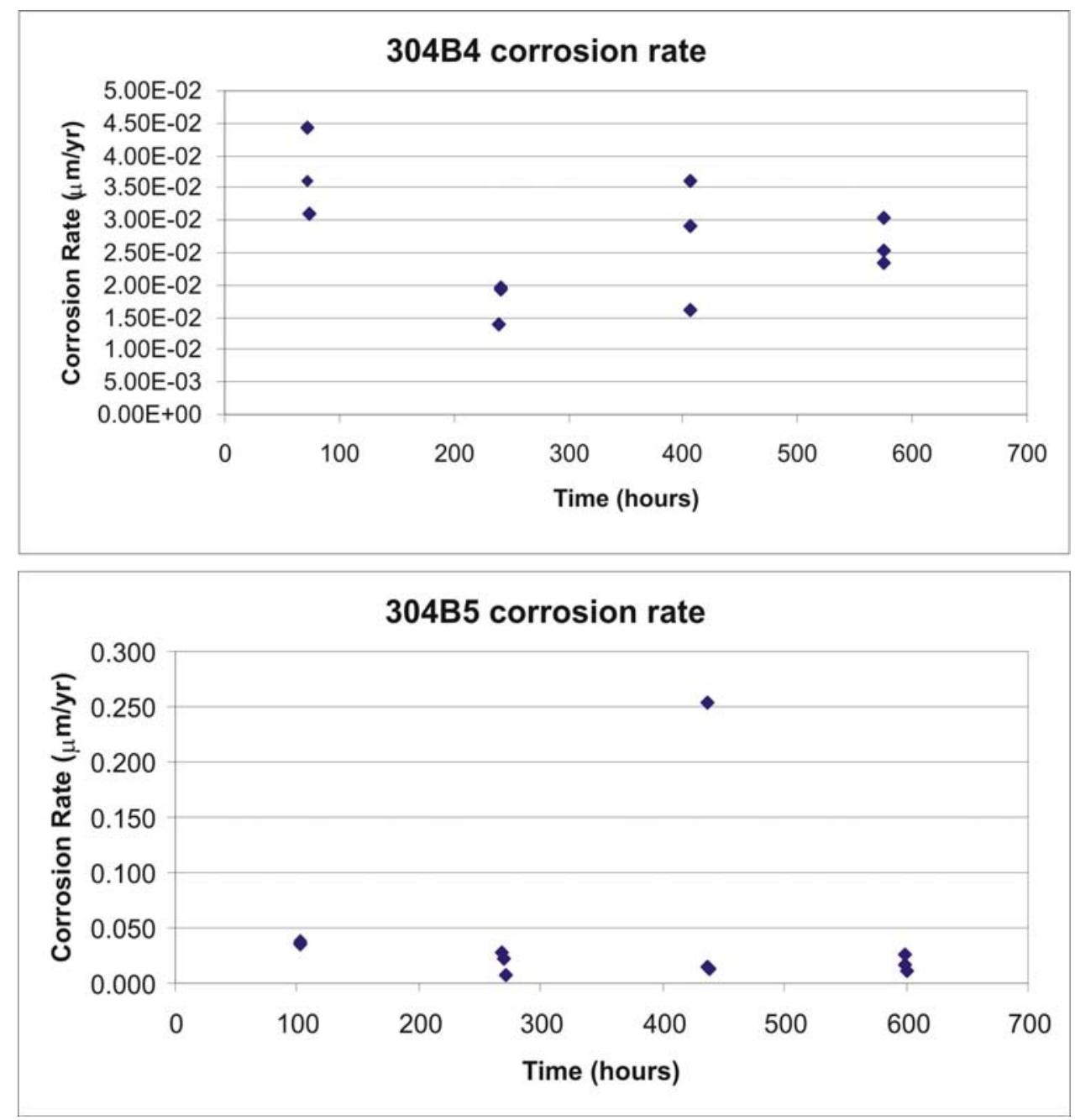

Figure 4. Corrosion rates versus time plots obtained by LPR measurements.

\subsection{Potentiodynamic Measurements}

The CPP sweeps for two specimens (94-1 and 95-7) are shown in Figure 5. The sweep for 304B4 was a second measurement, as the $E_{b d}$ threshold $\left(1 \mu \mathrm{m} / \mathrm{cm}^{2}\right)$ was barely reached on the initial sweep, which had an anodic limit of $0.6 \mathrm{~V}$. The second sweep was very similar to the initial sweep but extended to $0.8 \mathrm{~V}$. The 304B5 showed a higher $\mathrm{E}_{\mathrm{bd}}$ but also showed a greater hysteresis and a lower $\mathrm{E}_{\mathrm{rp}}$. This data contrasts with that observed under similar conditions with only a short immersion time (1 hour) prior to testing. In those tests, the $\mathrm{E}_{\mathrm{bd}}$ value was between $0.2 \mathrm{~V}$ and $0.3 \mathrm{~V}$ and significant hysteresis and more negative $\mathrm{E}_{\mathrm{rp}}$ was observed. ${ }^{8}$ Thus, there appears to be an effect from an initially more active surface that affects the susceptibility to localized corrosion in these relatively benign environments. 


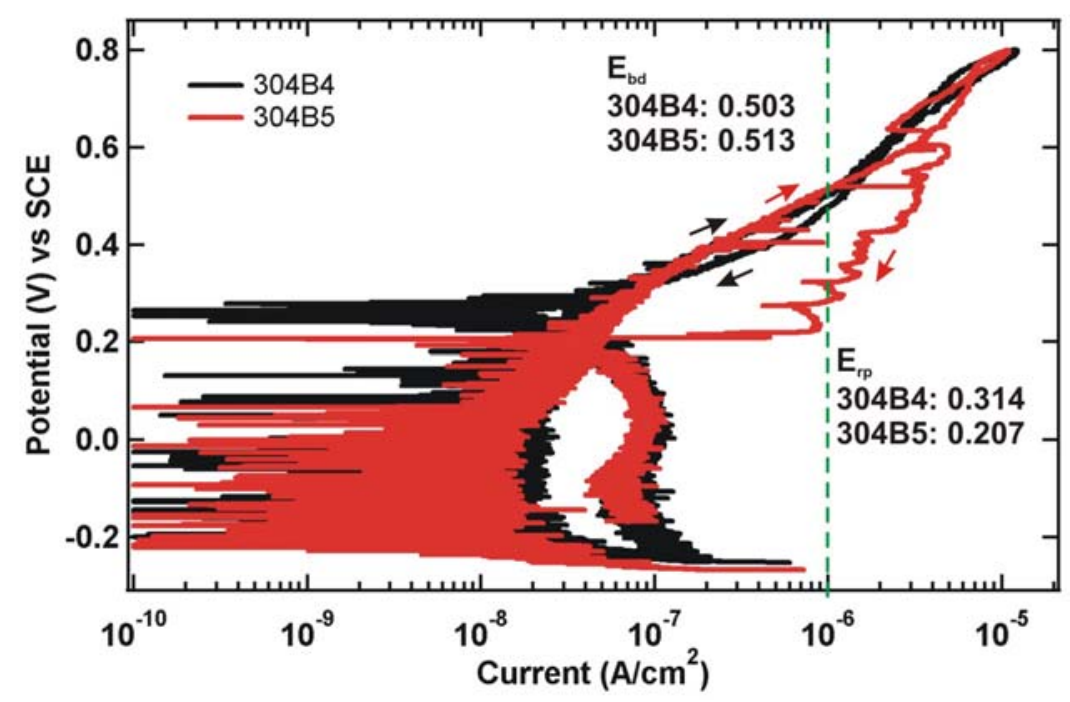

Figure 5. CPP curves for specimens 94-1 and 95-7.

\subsection{Post-Test Observations}

The test solutions were clear and colorless after the test. Approximately $10 \%$ of the original solution volume was lost due to evaporation. No sign of precipitates were observed. The specimens did not show any apparent sign of change, even before descaling. Photographs of the specimens after descaling are shown in Figures 6 and 7. The only specimens showing any surface appearance to the eye are specimens 94-1 and 95-7, which had a CPP test performed at the end of the test. Those specimens had a staining around the edges of the crevice former, which is likely a thin layer of corrosion product. No sign of gross free surface pitting or crevice damage were observed as a result of the test.

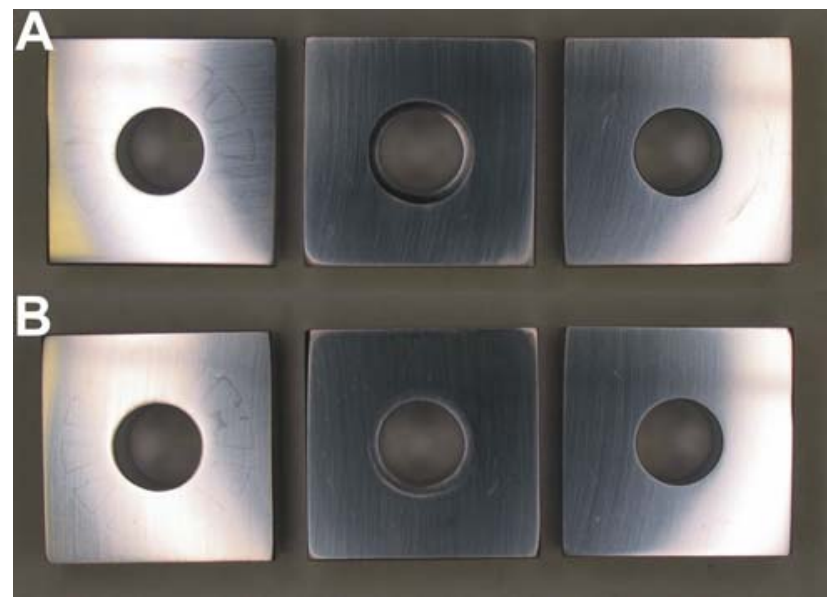

Figure 6. Specimen appearance of 304B4 specimens (94-1, 94-2, and 94-5, left to right).

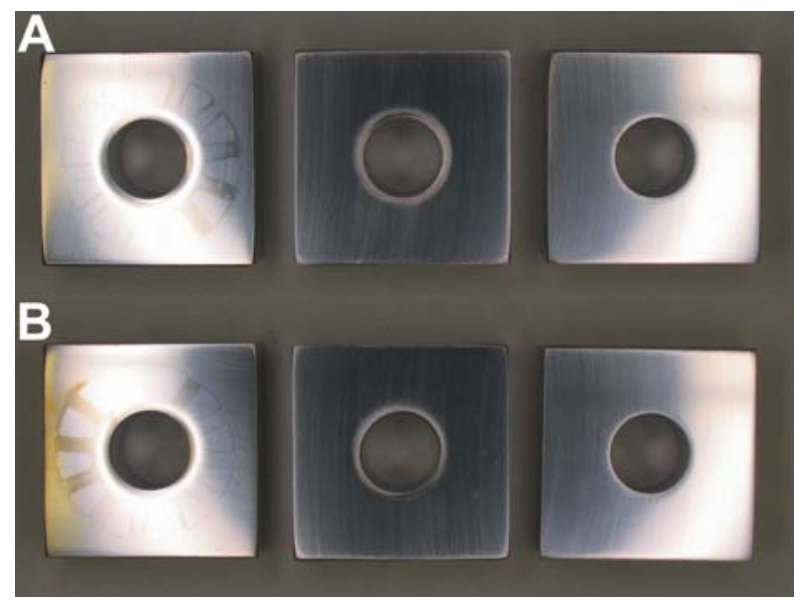

Figure 7. Specimen appearance of 304B5 specimens (95-7, 95-8, and 95-9, left to right). 
Weight loss due to the tests was used to calculate a CR. Table 7 displays the weight loss and calculated corrosion rates. Note that the test time does not permit very accurate CR measurement due to small mass changes observed. In addition, a milder descaling treatment was performed due to problems with etching at secondary phase particles using ASTM prescribed conditions ${ }^{9}$ in exploratory testing. The same nitric acid cleaning solution was used, but was performed at room temperature versus $60^{\circ} \mathrm{C}$ designated in Annex A1 Designation C.7.1. ${ }^{9}$ Thus, incomplete removal of corrosion scale was possible. Due to the light nature of the damage, this is likely a small effect. The corrosion rates are similar to those measured by LPR and show very passive characteristics under these conditions. The weight loss values for CPP tested specimens (94-1 and 95-7) were not significantly different.

Table 7. Data from gravimetric analysis.

\begin{tabular}{ccc}
\hline Specimen & $\begin{array}{c}\text { Weight loss } \\
(\mathrm{g})\end{array}$ & $\begin{array}{c}\mathrm{CR} \\
(\mu \mathrm{m} / \mathrm{yr})\end{array}$ \\
\hline $94-1$ & $6.00 \mathrm{E}-05$ & 0.0641 \\
$94-2$ & $9.00 \mathrm{E}-05$ & 0.0956 \\
$94-3$ & $4.00 \mathrm{E}-05$ & 0.0428 \\
$95-7$ & $7.00 \mathrm{E}-05$ & 0.0740 \\
$95-8$ & $5.00 \mathrm{E}-05$ & 0.0528 \\
$95-9$ & $4.00 \mathrm{E}-05$ & 0.0423 \\
\hline
\end{tabular}

Light optical microscopy (LOM) was used to observe surface damage to the specimen. Some examples of damage are shown in Figure 8. Only isolated damage that was clearly corrosion in origin was observed. Some damage appeared to be due to morphology of the specimen as the pitting signatures were very directional. Most of the localized corrosion damage was observed on the specimens used for CPP. These also showed an orange stain (Figure 8 Specimen 95-7) around the crevice formers due to iron oxide precipitates.

\subsection{Solution Analysis}

Solutions were collected just prior to performing CPP scans on the final day of immersion. These were analyzed for dissolved metals content $(\mathrm{Fe}, \mathrm{Cr}, \mathrm{Ni}, \mathrm{Mn})$ and dissolved boron. Table 8 shows the results from the two tests. Note that some of the boron could be from the sample vessel and glass solution containers. The glassware contribution was not accounted for in Table 8. Solution specimens are captured in polyethylene bottles

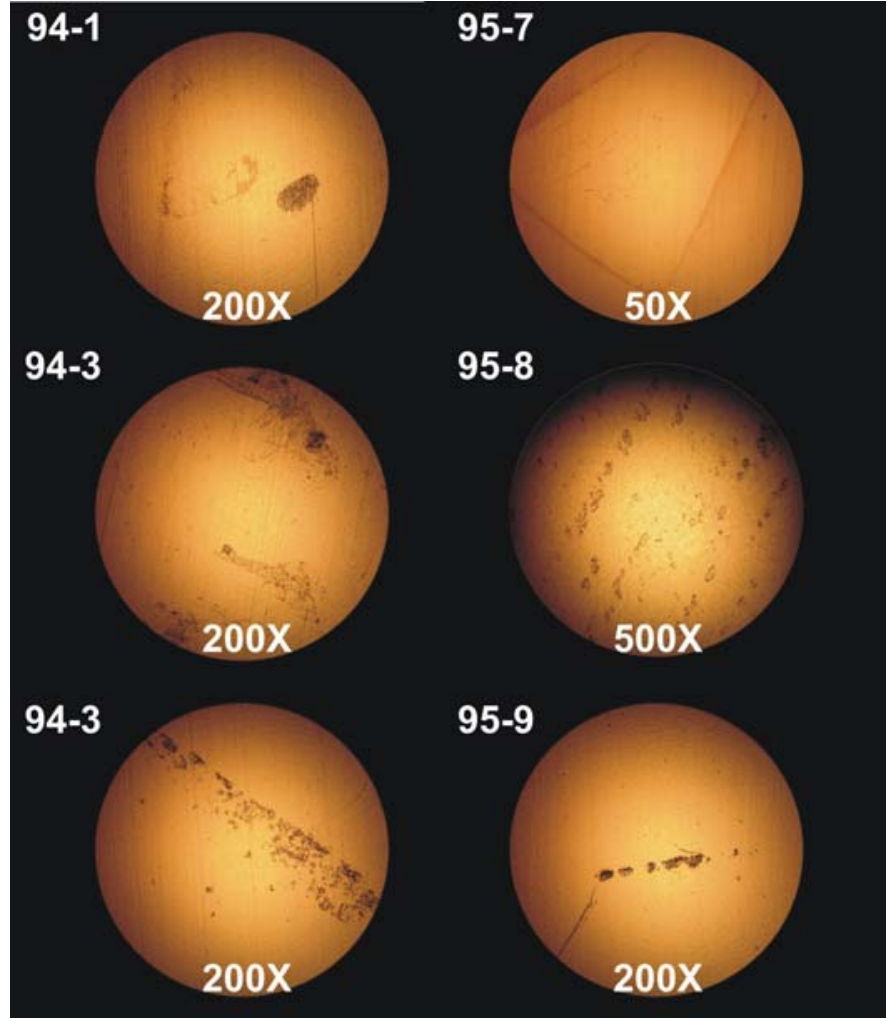

Figure 8. LOM of corrosion specimens after descaling. 
for possible future analysis. Obtaining a blank solution (no specimens immersed) from the solution vessel using similar conditions would also be needed. The final $\mathrm{pH}$ values were also collected and independently analyzed, with Test 032107 having a pH of 7.81 and Test 032807 having a pH of 6.73 .

Table 8. Concentration of dissolved components in $\mu \mathrm{g} / \mathrm{L}$.

\begin{tabular}{|l|c|c|c|c|}
\hline & $\mu \mathrm{g} / \mathrm{L}$ & $\begin{array}{c}\mathrm{ppm} \\
(\mu \mathrm{g} / \mathrm{g})\end{array}$ & $\mu \mathrm{g} / \mathrm{L}$ & $\begin{array}{c}\mathrm{ppm} \\
(\mu \mathrm{g} / \mathrm{g})\end{array}$ \\
\hline Boron & 852 & $8.55 \mathrm{E}-01$ & 658 & $6.60 \mathrm{E}-01$ \\
\hline Chromium & $\mathrm{ND}$ & $\mathrm{ND}$ & 1.5 & $1.5 \mathrm{E}-03$ \\
\hline Iron & $\mathrm{ND}$ & $\mathrm{ND}$ & $\mathrm{ND}$ & $\mathrm{ND}$ \\
\hline Manganese & 2.06 & $2.07 \mathrm{E}-03$ & 2.24 & $2.25 \mathrm{E}-03$ \\
\hline Nickel & 524 & $5.26 \mathrm{E}-01$ & 585 & $5.87 \mathrm{E}-01$ \\
\hline
\end{tabular}




\section{CONCLUSIONS}

Corrosion testing was performed on two heats of borated stainless steels: 182194 a 304B4 composition and 182195 a 304B5 composition. The environment was designated as representative of a breached waste package. The general corrosion performance of the alloys was below $0.1 \mu \mathrm{m} / \mathrm{yr}$ as measured by LPR and gravimetric analysis. $\mathrm{E}_{\text {corr }}$ measurements show that under aeration, the $\mathrm{E}_{\text {corr }}$ shifted positive to a value is slightly above $0 \mathrm{~V}$ versus SCE. The value for 304B4 was slightly more positive. Isolated localized corrosion damage was observed, primarily on specimens that were used for CPP testing at the end of the testing period. The CPP tests show that extended immersion in the solution appeared to reduce the susceptibility as evidenced by more positive $E_{b d}$ and $E_{r p}$ values over those of freshly immersed specimens.

While these results show evidence of a stable material under these conditions, the testing was focused to one environmental condition for a relatively short exposure period. Longer testing periods under a wider range of conditions is recommended for determining the reasonable bounds of stability of this type of material (temperature, chemistry, and specimen composition) pertaining to general and localized corrosion. 


\section{REFERENCES}

1. ASTM A887-89(2004), "Standard Specification for Borated Stainless Steel Plate, Sheet, and Strip for Nuclear Application," American Society for Testing and Materials.

2. PLN-2320 “Corrosion Testing of Neutron Absorber Alloys," Rev 2, Material Sciences Department, Idaho National Laboratory, 16 April, 2007.

3. PLN-2313, "Experimental Plan for Corrosion Testing of Neutron Absorbing Materials," Rev 1, Material Sciences Department, Idaho National Laboratory, March 23, 2007.

4. PLN-2314, "Experimental Procedures for Corrosion Testing of Neutron Absorbing Materials," Rev 0, Material Sciences Department, Idaho National Laboratory, December 20, 2006.

5. TWP-MGR-MD-000038 Rev 00, “Technical Work Plan for Boron Stainless Steel Testing” Yucca Mountain Project, January 2007

6. DWG 630285, “Crevice Corrosion Specimen,” Rev 2, Dec. 19, 2006.

7. D. V. Fix, J. C. Estill, L. L. Wong, and R. B. Rebak, "General and Localized Corrosion of Austenitic and Borated Stainless Steels in Simulated Concentrated Ground Waters," American Society of Mechanical Engineers Pressure Vessels and Piping Division (ASME-PVP) Conference, San Diego, California, July 2004.

8. T. Lister, R. Mizia, B. Matteson, and H. Tian, Electrochemical Testing of Neutron Absorbing Materials, INL/EXT-06-11772, Idaho National Laboratory, October 31, 2006.

9. ASTM G1-03(2003), "Standard Practice for Preparing, Cleaning, and Evaluating Corrosion Test Specimens" American Society for Testing and Materials. 